\title{
Migration Trends of Pharmacy Students of Pakistan: A Study Investigating the Factors Behind Brain Drain of Pharmacy Professionals from Pakistan
}

\author{
Atta Abbas Naqvi ${ }^{1 *}$, Fatima Zehra², Syed Baqir Shyum Naqvi ${ }^{3}$, Rizwan Ahmad ${ }^{4}$, Niyaz Ahmad ${ }^{5}$, \\ Saman Usmani ${ }^{3}$, Sehrish Badar ${ }^{3}$, Ishrat Younus ${ }^{3}$, Sarah Jameel Khan ${ }^{3}$ \\ 1'Department of Pharmacy Practice, College of Clinical Pharmacy, University of Dammam, Dammam 31441, SAUDI ARABIA. \\ ${ }^{2}$ Department of Social Sciences, Shaheed Zulfikar Ali Bhutto Institute of Science and Technology (SZABIST), Karachi 75600, \\ PAKISTAN. \\ ${ }^{3}$ Faculty of Pharmacy, Hamdard University, Madinat-ul-Hikmah, Sharae-al-Hikmah, Muhammad Bin Qasim Avenue, Karachi 74600, \\ PAKISTAN. \\ ${ }^{4}$ Natural Products and Alternative Medicines, College of Clinical Pharmacy, University of Dammam, Dammam 31441, SAUDI ARABIA. \\ ${ }^{5}$ Department of Pharmaceutics, College of Clinical Pharmacy, University of Dammam, Dammam 31441, SAUDI ARABIA.
}

\begin{abstract}
Background: Pakistan has witnessed a rise in the migration of professionals from the country in the last few years eventually leading to a brain drain. It is believed that the pharmacy students of Pakistan are ingrained with migration tendency. This study aimed to find out the factors influencing the trend, country of choice and reasons for migration. The study also looked into hurdles anticipated by the students during and after migration. Methods: A cross sectional study of 5 month duration was conducted in 3 cities of Pakistan targeting pharmacy students with a survey questionnaire. A total of 539 responses were gathered and analyzed in SPSS version 20. Descriptive statistics, cross tabs and chi square test were used. Results: The prevelance of emigration was found to be $94.06 \%(91.72 \%-95.90 \%$ for $95 \% \mathrm{Cl})$. The mean value of level of urgency was reported at $6.42 / 10$ (SD 2.49). Lack of infrastructure for pharmacists and security issues in the country were major push factors for Pakistan $(41.4 \%)$. Tough pharmacy license exam was reported as a major push factor for developed countries (21\%). Family ties $(46.2 \%)$ and desire to serve the country $(33.6 \%)$ were major pull factors of Pakistan. More employment opportunities $(24.7 \%)$ and lucrative salary $(17.8 \%)$ were major pull factors for developed countries. USA was chosen as the most favored country for migration $(24.9 \%)$ followed by Canada $(21.9 \%)$. Conclusion: The pharmacy students appeared more poised to emigrate from Pakistan with high urgency. This idea was supported by pull factors of developed countries and push factors of Pakistan however, pull factors of Pakistan appeared promising in reducing the level of brain drain but it was unclear as to what extent this could overcome migration tendency.
\end{abstract}

Key words: Migration, Brain drain, Pharmacy, Students, Pakistan, Human migration, Pharmacy education, Pharmacy practice.

\section{INTRODUCTION}

Migration of health professionals in substantial numbers during the last few years has become a huge concern for developing countries. This movement of health personnel from developing to developed countries is referred as 'Brain Drain' and occurs in search of higher income, employment options and better quality of life. However due to this loss of skilled personnel, there has been a devastating impact on the economy and especially the health system of these developing countries. It is a matter of grave concern for Pakistan since it is among the 57 countries of the world that are battling with a severe crisis of the human resource for health. ${ }^{1}$
Submission Date: 18-10-2016; Revision Date: 28-11-2016; Accepted Date: 03-01-2017

DOI: 10.5530/ijper.51.2.25 Correspondence: Atta Abbas Naqvi, Lecturer, Department of Pharmacy Practice, College of Clinical Pharmacy, University of Dammam, Dammam 31441 , SAUDI ARABIA.

Tel: 00966-53-7404522 E-mail: bg33bd@student. sunderland.ac.uk

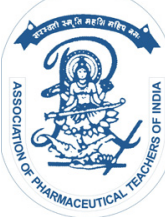

www.ijper.org 
According to the Bureau of Emigration and Overseas Employment Pakistan, around 1000-1500 physicians leave Pakistan annually. It is estimated that 10653 doctors and 6499 nurses have migrated from Pakistan to other countries during the period of 1971-2011. ${ }^{2}$ However little has been documented about the extent of the brain drain of pharmacists in particular. There are a total of 34 pharmacy institutions in Pakistan as recognized by the Pharmacy Council of Pakistan (PCP) that are offering degree programs in Pharmacy. Seventeen (17) are in the public sector while 17 are in the private sector. ${ }^{3}$ Figures from the year 2011 revealed that at least 1500-1800 students were graduating annually from these institutions. It is expected that this figure would have now increased to 2500-3000 students graduating each year. According to WHO's Implementation Strategy Report 2011, Pakistan has a total of 32,511 registered pharmacists. On the other hand, for a population of over 170 million, at least 62,085 pharmacists are necessary; consequently we find that there is a shortfall of almost 29, 574 pharmacy professionals in the country. ${ }^{4}$ Magnitude of the issue can be further understood through the health workforce density measure as calculated by World Health Organization (WHO). Health workforce density is measured per 10000 population. As of 2010, Pakistan has a low pharmacist workforce density which is below one as compared to a high of 11 per 10,000 in France and 9 per 10,000 in the United States of America (USA). ${ }^{5}$ Licensed pharmacists for all sectors in Pakistan are 0.61 per 10,000 population where as in the public sector it is merely 0.092 pharmacists per 10,000 people. ${ }^{6}$ This situation has become more complex and a further shortage of pharmacy professionals is expected to be created as several trained pharmacists continue to leave the country and many final year pharmacy students aspire to move to developed countries after graduation.

It is noteworthy to mention that the number of years of pharmacy degree program vary country to country. Thus, to overcome the differences in years as well as curricula of program, various equivalency exams and procedures have been employed by different countries. ${ }^{7.8}$ But despite the equivalency exams and complicated license obtaining procedures no negative effect is observed on the trend of migration. On the contrary, a significant increase in migration rate is observed particularly in fresh pharmacy professionals from developing countries. In fact, students are more geared towards preparation of equivalency exams during the final year of their undergraduate degree.

There are a number of reasons that encourage pharmacists in developing countries such as Pakistan to leave their country and these are commonly referred as push factors of migration. These include lack of career opportunities, uncertain political and social environment in the country, low salaries for pharmacy professionals as well as poor and de-motivating working conditions. On the other hand, there are various factors that 'pull' young pharmacy professionals from Pakistan to these developed countries such as USA, Australia, Canada and New Zealand. These include higher salaries and remuneration, better quality of life, attractive immigration prospects and greater opportunities for professional development. . So contrary to popular belief that brain drain is due to economic push and pull factors, it is found that it is happening due to a combination of social, economic as well as psychological factors that encourage professional to migrate from their home country to other developed countries.

There is a dearth of research literature concerning migration of pharmacists. This study was aimed at investigating the viewpoints of pharmacy students of three major cities of Pakistan regarding the factors influencing the trend, country of choice and reasons for migration. In addition, the study also looked into hurdles anticipated by the students during and after migration.

\section{MATERIALS AND METHODS}

A cross sectional study was conducted among pharmacy teaching institutes of Islamabad, Karachi and Lahore, Pakistan during February 2016 to June 2016. The study adhered to STROBE guidelines for reporting cross sectional studies.

\section{Venue of the study}

Islamabad is the federal capital of Pakistan with 3 private sector pharmacy teaching universities with yearly intake of 260 undergraduate students. ${ }^{10}$ Lahore is the provincial capital of Punjab province with 3 public sector and 4 private sector pharmacy teaching institutes with an annual intake of 955 undergraduate students of pharmacy. ${ }^{11}$ Karachi is the largest and most populous city of Pakistan and the capital of Sindh province. There are 3 public sector and 6 private sector institutes with a yearly intake of 1220 undergraduate students. ${ }^{3,12}$ The information presented is currently updated as of now.

\section{Target population and exclusion criteria}

The target population for this study was pharmacy students of Pakistan. It included those who were currently enrolled in Pharm.D (Doctor of Pharmacy) program in a Pakistani pharmacy institution and those who were pharmacy residents fulfilling the co-requisite of the degree program. Those who were enrolled in B.Pharm 
(Bachelor of Pharmacy) program or any other program of Pharmacy other than Pharm.D were not included. Those who completed their Pharm.D but did not undergo residency were also excluded. Drop out pharmacy students were not included. Students pursuing higher degrees in Pakistan were also not included. Pharmacy students who were confused or lacked seriousness towards questionnaire were excluded. It was determined from their feedback on the questionnaire. In addition, questionnaires with missing data were also excluded.

\section{Sample size calculation and procedure}

The sample size calculated was based on current number of student intakes of pharmacy institutions approved by the Pharmacy Council of Pakistan (PCP). It was done by multiplying respective intake of each city with 5 (assuming figure to remain same in all 5 professional years of Pharm.D program) in order to get a cumulative figure of pharmacy students in a particular city. Subsequently all 3 figures obtained from Karachi, Lahore and Islamabad were added to get a general population of pharmacy students.

The population of undergraduate pharmacy students of Islamabad (1300), Lahore (4775) and Karachi (6100) summed up to a total of 12175 undergraduate pharmacy students. The number of students graduating every year reported by Azhar et.al was $2587 .{ }^{13}$ This figure was also added to the total population to get a final figure of 14762 since those who graduate undergo compulsory residency to fulfill degree requirement. The sample size was then calculated using online sample size calculator from Creative Research Systems ${ }^{\circledR}$ taking confidence level at $95 \%$ and confidence interval of $5 \%$, population of pharmacy students entered was 14762 and sample size needed was found to be $374(\mathrm{~N}=374) .{ }^{14}$ The survey was completed with a total of 539 responses.

Convenience sampling procedure was employed i.e. the students with close proximity to the researcher were approached in their free (off-peak) time. The reason to use convenience sampling was to measure the migration trend among pharmacy students which is presumed not to be affected within the pharmacy student group or location of the group such as cities/ universities.

\section{Operational definitions}

\section{Pharmacy students of Pakistan}

The students enrolled in a Doctor of Pharmacy (Pharm.D) degree program and/or undergoing residency as a compulsory requirement of the degree from a public or private sector pharmacy teaching institute of Pakistan recognized by the Pharmacy Council of Pakistan. ${ }^{3,15}$

\section{Pull factors}

Circumstances that attract or facilitate movement of pharmacy professionals to work/ stay in that country. ${ }^{16}$

\section{Push factors}

Circumstances that drive pharmacy professionals away from working or staying in a particular place or country. ${ }^{16}$

\section{Pharmacy licensing exam}

Exams related to the field of pharmacy conducted by respective pharmacy regulatory authority that are needed by pharmacy graduates to clear/pass in order to practice the profession in a country. ${ }^{16}$

\section{Merit}

Those students who cleared the university's entrance exam/interview and based on their secondary school and higher secondary school results were placed on a list known as merit list with average minimal fee less than USD 859 i.e. PKR 90,000 (Pakistani Rupee Ninety thousand only) per annum. This is applicable to the public universities.

\section{Research instrument and piloting}

The research instrument consisted of a questionnaire in English language partially adopted from Sheikh et al. $2012,{ }^{16}$ developed and modified through experts who were professors, clinical pharmacists, pharmacy teachers and student career counselors at pharmacy teaching institutes of Pakistan. The 35 point questionnaire consisted of 5 open and 30 close ended questions. Open ended questions were incorporated to comprehensively extract the students' response. Thematic analysis was conducted for the aforementioned.

The research tool was divided in to 3 sections; section - I (demographic information), section - II (contributing factors to stay or emigrate from the country) and section - III (attitudes toward migration, selecting a career abroad and pharmacy licensing examination and related details). A 5-point Likert scale was employed in section III to assess the tendency of the respondents to a particular variable. The piloting of the questionnaire was done on 18 pharmacy students from 4 different universities. It took an average 13 minutes to fill in the response. After completion of the pilot phase, the study commenced.

\section{Ethical review and consent}

The study was approved by the Institutional Research Review Board (Department of Pharmacy), Clifton Hospital Karachi, 75600, Pakistan (Approval \# CH10398-e-3108). Furthermore, prior to the data collection the respondents were briefed about the study and its 


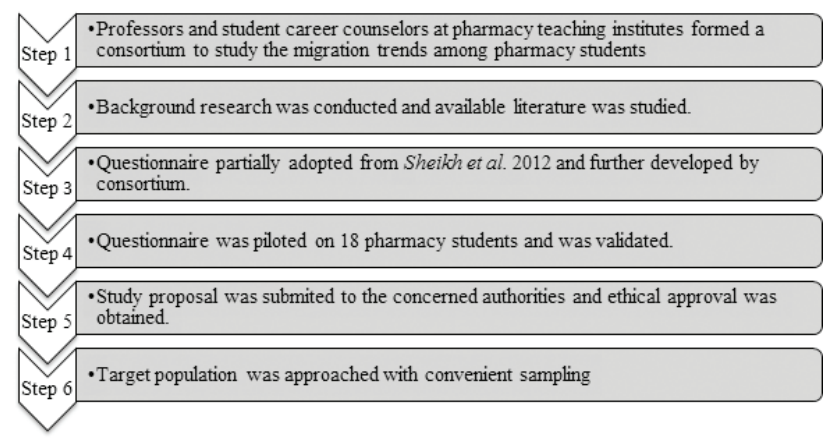

Figure 1: Logical sequence of methodology.

protocol by research volunteers. The respondents were also explained about the significance of the study and their written consent was sought. Those who consented to participate were handed questionnaire.

\section{Statistical analysis}

The data was entered in SPSS v20 (Statistical Package for Social Sciences version 20). The study employed descriptive statistics and frequencies i.e. mean $(X)$, standard deviations (SD) and percentages (\%). Chi square $(X 2)$ test and cross tabulation was also employed. A significance level $(\alpha)$ was determined at 0.05 . The logical sequence of methodology is presented in Figure 1.

\section{RESULTS}

\section{Response rate}

A total of 721 questionnaires were handed to pharmacy students of; Islamabad ( $\mathrm{N}=155)$, Lahore $(\mathrm{N}=274)$ and Karachi $(\mathrm{N}=292)$ out of which 634 were received. Twenty nine $(\mathrm{N}=29)$ surveys were incomplete, 31 students appeared non serious hence their questionnaire were also excluded and 35 surveys received from student who were confused were also rejected. The total surveys available for data entering and analysis were 539 giving completion rate (CR) of $85 \%$ and a response rate (RR) of $74.7 \%$.

\section{Demographic Information}

Out of total of 539 responses, majority of the students were in age groups between 18 to 23 years $(\mathrm{N}=463$, $85.9 \%$ ) followed by slightly more than a tenth proportion between $24-27$ years $(\mathrm{N}=72,13.4 \%)$ and very few above 27 years $(\mathrm{N}=4,0.7 \%)$. The mean age was 21.25 (SD 2.08). The female students appeared to be more in number $(\mathrm{N}=401,74.4 \%)$. The year wise distribution of pharmacy students appeared as; Pharm.D $1^{\text {st }}$ Prof year $(\mathrm{N}=126,23.4 \%), 2^{\text {nd }}$ Prof year $(\mathrm{N}=112$, $20.8 \%), 3^{\text {rd }}$ Prof year $(\mathrm{N}=106,19.7 \%), 4^{\text {th }}$ Prof year $(\mathrm{N}=70,13.0 \%), 5^{\text {th }}$ Prof year $(\mathrm{N}=90,16.7 \%)$ and pharmacy students who had completed their education and were interns or residents at a health care setting $(\mathrm{N}=35,6.5 \%)$.

In terms of nationalities, almost all of the students $(\mathrm{N}=525,97.4 \%$ ) held Pakistani nationality only. Regarding social status, an overwhelming majority appeared single $(\mathrm{N}=512,95.5 \%)$. More than half of the target segment $(\mathrm{N}=401,74.4 \%)$ was on merit. A quarter proportion $(\mathrm{N}=135,25 \%)$ was studying on self-finance seats with a fee above USD 1909 i.e. PKR 200,000 (Pakistani rupee two hundred thousand only) per annum. Half of the target segments studied in private sector university $(\mathrm{N}=389,72.2 \%)$. The summary of demographic information is tabulated in Table 1.

\section{Prevalence and urgency of migration}

The intention to migrate was calculated in terms of prevalence by Medcalc ${ }^{\circledR}$ and was found to be $94.06 \%$ $(91.72 \%$ - $95.90 \%$ for $95 \%$ CI). The mean value for level of urgency was analyzed using scale of zero (0) i.e. no urgency, to ten (10) i.e. maximum urgency. It was reported at 6.42 (SD 2.49). The summary of migration information is presented in Table 2.

\section{Career Choice in Pakistan}

Pharmacy students who wished to pursue their career in Pakistan, predominantly, selected pharmaceutical industry $(\mathrm{N}=262,48.6 \%)$ however, an opposite trend was observed when students were asked about their career choice abroad as majority selected clinical and hospital pharmacy $(\mathrm{N}=332,61.6 \%)$ as their career choice. The summary of career choices for pharmacy students of Pakistan is tabulated in Table 3.

\section{Factors influencing migration trends}

The questionnaire included questions related to the factors which influenced the migration intention of the students. These factors were formulated as pull and push factors.

\section{Pull factors of Pakistan}

The major factors due to which the students appeared hesitant to go abroad were their strong family ties $(\mathrm{N}=249,46.2 \%)$ and the desire to serve the country $(\mathrm{N}=181,33.6 \%)$. Additionally, students expected that Pakistan will provide more job opportunities $(\mathrm{N}=19$, $3.5 \%$ ) for graduates with high degree job satisfaction $(\mathrm{N}=24,4.5 \%)$.

\section{Push factors of Pakistan}

Majority of the students $(\mathrm{N}=223,41.4 \%)$ indicated lack of infrastructure for pharmacists in Pakistan's health care system as a factor which prompts the idea 


\begin{tabular}{|c|c|c|c|c|}
\hline S.No & Demographics & Observed (N) & Percentage (\%) & $P$ value \\
\hline \multirow[t]{5}{*}{1} & \multicolumn{3}{|c|}{ Age Group } & $0.0001(<0.01)$ \\
\hline & Between $18-23$ years & 463 & 85.9 & \\
\hline & Between $24-27$ years & 72 & 13.4 & \\
\hline & Above 27 years & 4 & 0.7 & \\
\hline & Total & 539 & 100 & \\
\hline \multirow[t]{4}{*}{2} & \multicolumn{3}{|c|}{ Gender } & $0.0001(<0.01)$ \\
\hline & Male & 138 & 25.6 & \\
\hline & Female & 401 & 74.4 & \\
\hline & Total & 539 & 100 & \\
\hline \multirow[t]{8}{*}{3} & Professional Years & & & $0.0001(<0.01)$ \\
\hline & Pharm.D $1^{\text {st }}$ Professional & 126 & 23.3 & \\
\hline & Pharm.D $2^{\text {nd }}$ Professional & 112 & 20.8 & \\
\hline & Pharm.D $3^{\text {rd }}$ Professional & 106 & 19.7 & \\
\hline & Pharm.D $4^{\text {th }}$ Professional & 70 & 13 & \\
\hline & Pharm.D $5^{\text {th }}$ Professional & 90 & 16.7 & \\
\hline & Pharmacy Resident (6 ${ }^{\text {th }}$ Year) & 35 & 6.5 & \\
\hline & Total & 539 & 100 & \\
\hline 4 & \multicolumn{3}{|c|}{ Nationality } & $0.0001(<0.01)$ \\
\hline & Pakistan & 525 & 97.4 & \\
\hline & Foreign Nationality & 2 & 0.4 & \\
\hline & Dual national & 12 & 2.2 & \\
\hline & Total & 539 & 100 & \\
\hline \multirow[t]{5}{*}{5} & \multicolumn{3}{|c|}{ Social status } & $0.0001(<0.01)$ \\
\hline & Single & 515 & 95.5 & \\
\hline & Married & 23 & 4.3 & \\
\hline & Divorced & 1 & 0.2 & \\
\hline & Total & 539 & 100 & \\
\hline \multirow[t]{5}{*}{6} & \multicolumn{3}{|c|}{ Admission Type } & $0.0001(<0.01)$ \\
\hline & Merit & 401 & 74.4 & \\
\hline & Self-finance & 135 & 25 & \\
\hline & Did not know & 3 & 0.6 & \\
\hline & Total & 539 & 100 & \\
\hline \multirow[t]{4}{*}{7} & \multicolumn{3}{|c|}{ University Type } & $0.0001(<0.01)$ \\
\hline & Private Sector & 389 & 72.2 & \\
\hline & Public Sector & 150 & 27.8 & \\
\hline & Total & 539 & 100 & \\
\hline
\end{tabular}

\section{Table 2: Summary of migration intention and urgency}

Migration intention

Prevalence rate of intention to migrate from Pakistan Migration urgency

Level of urgency to migrate from Pakistan

\begin{tabular}{|c|c|c|c|}
\hline & \multicolumn{3}{|c|}{$95 \%$ Confidence interval } \\
\hline $94.06 \%$ & \multicolumn{3}{|c|}{$91.72 \%-95.90 \%$} \\
\hline Mean & Minimum & Maximum & SD \\
\hline 6.42 & 0 & 10 & 2.49 \\
\hline
\end{tabular}




\begin{tabular}{|c|c|c|c|c|}
\hline S.No & Career choices & Sample (N) & Percentage (\%) & $P$ value \\
\hline \multirow[t]{7}{*}{1} & \multicolumn{3}{|l|}{ Pharmacy career in Pakistan } & $0.0001(<0.01)$ \\
\hline & Pharmaceutical Industry & 262 & 48.6 & \\
\hline & Clinical \& hospital pharmacy & 232 & 43 & \\
\hline & Community \& retail pharmacy & 7 & 1.3 & \\
\hline & Teaching and academics & 28 & 5.2 & \\
\hline & Others & 10 & 1.9 & \\
\hline & Total & 539 & 100 & \\
\hline \multirow[t]{8}{*}{2} & Pharmacy career abroad & & & $0.0001(<0.01)$ \\
\hline & Pharmaceutical Industry & 127 & 23.6 & \\
\hline & Clinical \& hospital pharmacy & 332 & 61.6 & \\
\hline & Community \& retail pharmacy & 47 & 8.7 & \\
\hline & Teaching and academics & 16 & 3 & \\
\hline & Research & 1 & 0.1 & \\
\hline & Others & 16 & 3 & \\
\hline & Total & 539 & 100 & \\
\hline
\end{tabular}

of moving abroad. Besides, second most common factor was security issue. $(\mathrm{N}=172,31.9 \%)$,

\section{Pull factors of foreign countries}

The dominant pull factor for abroad are facilities and opportunities with the most common factor being the unparallel employment opportunities $(\mathrm{N}=133,24.7 \%)$ followed by lucrative salaries $(\mathrm{N}=98,17.8 \%)$.

\section{Push factors of foreign countries}

The bulk of respondents $(\mathrm{N}=113,21 \%$ ) reasoned tough pharmacy licensing examinations as major hurdle to move abroad followed by visa and travel issues. $(\mathrm{N}=81,15 \%)$. Similarly, employment competition $(\mathrm{N}=53,9.8 \%)$ was also highlighted as push factor. The summary of all factors influencing migration trends of pharmacy students of Pakistan are presented in Table 4. The students were also asked if their decision is likely to change if the push factors of Pakistan are neutralized. The responses gathered on Likert 5 point scale (for degrees of agreement and disagreement) was set as; value one (1) i.e. willingness to change and value five (5) i.e. unwillingness. In terms of proportion, major segment $(\mathrm{N}=235,43.6)$ expressed willingness to change their decision followed by a third segment $(\mathrm{N}$ $=158,29.3 \%)$ indicating the notion that they may change their decision. The mean score on Likert Scale was 2.22 (SD 1.3) which implies that the general perception of respondents lies in the probability to change the decision. Similarly for the foreign countries, a high percentage of students $(\mathrm{N}=235,43.6 \%)$ indicated their decision to change if the push factor of abroad is neutralized followed by those $(\mathrm{N}=172$, $31.9 \%$ ) who may change their decision. The mean score on Likert Scale was 2.11 (SD 1.1) which implies that the general perception of respondents will most probably change following a neutralized push factor of abroad. The summary of results is tabulated in table 5 .

\section{Migration destination and reasons for choice}

The students were asked about country of choice for migration. Majority of the students $(\mathrm{N}=$ 134, 24.9\%) mentioned USA as their choice. Second most favored country for migration was Canada highlighted by a fifth proportion of the respondents $(\mathrm{N}=118,21.9 \%)$ while slightly less than a fifth of target segment $(\mathrm{N}=89,16.5 \%)$ mentioned Australia as their country of choice for migration. Besides this, some students $(\mathrm{N}=25,4.6 \%)$ had the desire to migrate to foreign country but they did not know their preference.

Furthermore, a quarter proportion of students $(\mathrm{N}=145$, $26.9 \%$ ) reasoned more opportunities for pharmacists as well as relatives living abroad. ( $\mathrm{N}=131,24.3 \%)$. Some students $(\mathrm{N}=41,7.6 \%)$ failed to provide any reason for their choice. The summary of country of choice and reasons for migration are tabulated in Table 6.

\section{Attitude towards migration}

The respondents were asked about staying in Pakistan despite security issues. The mean score on Likert Scale was 2.44 (SD 1.0) which shows general perception of respondents to move out of Pakistan or stay unwillingly. The respondents were also asked if they were willing to 


\begin{tabular}{|c|c|c|c|c|}
\hline S.No & Factors influencing migration trends & $\begin{array}{c}\text { Sample } \\
\text { (N) }\end{array}$ & $\begin{array}{c}\text { Percentage } \\
(\%)\end{array}$ & $P$ value \\
\hline \multirow[t]{10}{*}{1.} & Pull factors of Pakistan & & & $0.0001(<0.01)$ \\
\hline & Family ties & 249 & 46.2 & \\
\hline & More employment opportunities & 19 & 3.5 & \\
\hline & Employment satisfaction & 24 & 4.4 & \\
\hline & Better life style & 30 & 5.6 & \\
\hline & Desire to serve country & 181 & 33.6 & \\
\hline & Religious reasons & 20 & 3.7 & \\
\hline & Wealth and property in Pakistan & 14 & 2.6 & \\
\hline & Commitments/ financial debt & 2 & 0.4 & \\
\hline & Total & 539 & 100 & \\
\hline \multirow[t]{8}{*}{2.} & Push factors of Pakistan & & & $0.0001(<0.01)$ \\
\hline & Harassment of pharmacists in Pakistan & 56 & 10.4 & \\
\hline & Favoritism in Pakistan & 65 & 12.1 & \\
\hline & Security issues & 172 & 31.9 & \\
\hline & Competition in employment & 22 & 4.1 & \\
\hline & Lack of infrastructure for pharmacists in health care system & 223 & 41.4 & \\
\hline & More than one above mentioned reason & 1 & 0.1 & \\
\hline & Total & 539 & 100 & \\
\hline \multirow[t]{12}{*}{3} & Pull factors of foreign countries & & & $0.0001(<0.01)$ \\
\hline & Lucrative salaries & 96 & 17.8 & \\
\hline & Quality training & 58 & 10.8 & \\
\hline & Employment satisfaction & 78 & 14.5 & \\
\hline & Better life style & 83 & 15.4 & \\
\hline & Relatives & 26 & 4.8 & \\
\hline & More employment opportunities & 133 & 24.7 & \\
\hline & Better work environment & 51 & 9.5 & \\
\hline & Interested to settle abroad & 8 & 1.5 & \\
\hline & Religious freedom & 5 & 0.9 & \\
\hline & More than one above mentioned reason & 1 & 0.1 & \\
\hline & Total & 539 & 100 & \\
\hline \multirow[t]{12}{*}{4} & Push factors of foreign countries & & & $0.0001(<0.01)$ \\
\hline & Tough pharmacy licensing exam & 113 & 21 & \\
\hline & Long duration of jobs & 37 & 6.9 & \\
\hline & Racism & 38 & 7.1 & \\
\hline & No top positions for Pakistanis & 80 & 14.8 & \\
\hline & Favoritism among nationalities & 52 & 9.6 & \\
\hline & Lack of opportunities for Pakistani pharmacists & 72 & 13.4 & \\
\hline & More competition & 53 & 9.8 & \\
\hline & Political issues & 12 & 2.2 & \\
\hline & Visa issues and related problems & 81 & 15 & \\
\hline & More than one above mentioned reason & 1 & 0.2 & \\
\hline & Total & 539 & 100 & \\
\hline
\end{tabular}




\section{Table 5: Summary of decision flexibility in response to neutralized push factor}

\begin{tabular}{|c|c|c|c|c|c|}
\hline S.No & Decision change if & $\begin{array}{c}\text { Sample } \\
\text { (N) }\end{array}$ & $\begin{array}{c}\text { Percentage } \\
(\%)\end{array}$ & $\begin{array}{l}\text { Mean Likert } \\
\text { Score }\end{array}$ & SD \\
\hline 1. & \multicolumn{5}{|c|}{ Push Factor of Pakistan neutralized } \\
\hline & Yes & 243 & 45.1 & & \\
\hline & Probably & 64 & 11.9 & & \\
\hline & May be & 158 & 29.3 & 2.22 & 1.3 \\
\hline & I will be reluctant & 18 & 3.3 & & \\
\hline & No & 56 & 10.4 & & \\
\hline & Total & 539 & 100 & & \\
\hline \multirow[t]{7}{*}{2.} & \multicolumn{5}{|c|}{ Push factor of foreign countries neutralized } \\
\hline & Yes & 235 & 43.6 & & \\
\hline & Probably & 88 & 16.3 & & \\
\hline & May be & 172 & 31.9 & 2.11 & 1.1 \\
\hline & I will be reluctant & 9 & 1.7 & & \\
\hline & No & 35 & 6.5 & & \\
\hline & Total & 539 & 100 & & \\
\hline
\end{tabular}

\begin{tabular}{|c|c|c|c|c|}
\hline S.No & Attributes & Observed (N) & Percentage (\%) & $P$ value \\
\hline 1 & \multicolumn{3}{|c|}{ Country of choice for migration } & $0.0001(<0.01)$ \\
\hline & Australia & 89 & 16.5 & \\
\hline & Canada & 118 & 21.9 & \\
\hline & USA & 134 & 24.9 & \\
\hline & UAE & 74 & 13.7 & \\
\hline & UK & 52 & 9.7 & \\
\hline & Kuwait & 5 & 0.9 & \\
\hline & Saudi Arabia & 30 & 5.6 & \\
\hline & South Africa & 2 & 0.4 & \\
\hline & Germany & 5 & 0.9 & \\
\hline & Malaysia & 5 & 0.9 & \\
\hline & Do not know & 25 & 4.6 & \\
\hline & Total & 539 & 100 & \\
\hline \multirow[t]{11}{*}{2} & \multicolumn{3}{|c|}{ Reason behind choosing country of choice } & $0.0001(<0.01)$ \\
\hline & More opportunities for pharmacy profession & 145 & 26.9 & \\
\hline & Relatives residing in the country & 131 & 24.3 & \\
\hline & Opportunities of further education for pharmacists & 13 & 2.4 & \\
\hline & Better salaries & 32 & 6 & \\
\hline & Favorite country by instinct & 21 & 3.9 & \\
\hline & No reason & 41 & 7.6 & \\
\hline & More bright future abroad & 104 & 19.3 & \\
\hline & Developed pharmacy setup & 46 & 8.5 & \\
\hline & Previous experience of living in country & 6 & 1.1 & \\
\hline & Total & 539 & 100 & \\
\hline
\end{tabular}




\section{Table 7: Attitude towards migration}

\begin{tabular}{|c|c|c|c|c|c|}
\hline S.No & Attitude towards migration & Sample (N) & Percentage (\%) & $\begin{array}{l}\text { Mean Likert } \\
\text { Score }\end{array}$ & SD \\
\hline 1. & \multicolumn{5}{|c|}{ Will to stay in Pakistan despite security issues } \\
\hline & Yes & 115 & 21.3 & & \\
\hline & It feels bad but yes & 164 & 30.4 & & \\
\hline & I have no choice & 203 & 37.7 & 2.44 & 1.0 \\
\hline & No & 21 & 3.9 & & \\
\hline & Did not know & 36 & 6.7 & & \\
\hline & Total & 539 & 100 & & \\
\hline \multirow[t]{7}{*}{2.} & \multicolumn{5}{|c|}{ Will to give up pharmacy profession for an unrelated profession abroad } \\
\hline & Yes & 65 & 12.1 & & \\
\hline & Probably & 50 & 9.3 & & \\
\hline & May be & 109 & 20.2 & 3.77 & 1.4 \\
\hline & I am reluctant & 35 & 6.5 & & \\
\hline & No & 280 & 51.9 & & \\
\hline & Total & 539 & 100 & & \\
\hline \multirow[t]{7}{*}{3.} & \multicolumn{5}{|c|}{ Will to change career domain of pharmacy if need be } \\
\hline & Yes & 92 & 17 & & \\
\hline & Probably & 65 & 12.1 & & \\
\hline & May be & 131 & 24.3 & 3.43 & 1.5 \\
\hline & I am reluctant & 23 & 4.3 & & \\
\hline & No & 228 & 42.3 & & \\
\hline & Total & 539 & 100 & & \\
\hline \multirow[t]{7}{*}{4.} & \multicolumn{5}{|c|}{ Intention to apply citizenship abroad if any opportunity arise } \\
\hline & Yes & 289 & 53.6 & & \\
\hline & Probably & 82 & 15.2 & & \\
\hline & May be & 107 & 19.9 & 2.00 & 1.3 \\
\hline & I am reluctant & 3 & 0.5 & & \\
\hline & No & 58 & 10.8 & & \\
\hline & Total & 539 & 100 & & \\
\hline \multirow[t]{7}{*}{5.} & \multicolumn{5}{|c|}{ Will to take family along after acquiring citizenship abroad } \\
\hline & Yes & 337 & 62.5 & & \\
\hline & Probably & 76 & 14.1 & & \\
\hline & May be & 62 & 11.5 & 1.81 & 1.2 \\
\hline & I am reluctant & 17 & 3.2 & & \\
\hline & No & 47 & 8.7 & & \\
\hline & Total & 539 & 100 & & \\
\hline \multirow[t]{7}{*}{6.} & \multicolumn{5}{|c|}{ Will to return to Pakistan after acquiring citizenship abroad } \\
\hline & Yes & 261 & 48.4 & & \\
\hline & Probably & 87 & 16.1 & & \\
\hline & May be & 117 & 21.7 & 2.09 & 1.2 \\
\hline & I am reluctant & 31 & 5.8 & & \\
\hline & No & 43 & 8 & & \\
\hline & Total & 539 & 100 & & \\
\hline \multirow[t]{7}{*}{7.} & \multicolumn{5}{|c|}{ Will to relinquish Pakistani nationality if required by laws of migrating country } \\
\hline & Yes & 96 & 17.8 & & \\
\hline & Probably & 71 & 13.2 & & \\
\hline & May be & 78 & 14.5 & 3.55 & 1.6 \\
\hline & I am reluctant & 27 & 5 & & \\
\hline & No & 267 & 49.5 & & \\
\hline & Total & 539 & 100 & & \\
\hline \multirow[t]{5}{*}{8.} & \multicolumn{5}{|c|}{ Will to migrate despite knowing that Pakistan needs pharmacy professionals } \\
\hline & Yes & 112 & 20.8 & & \\
\hline & It feels bad but yes & 212 & 39.3 & 2.19 & 0.7 \\
\hline & No & 215 & 39.9 & & \\
\hline & Total & 539 & 100 & & \\
\hline
\end{tabular}


Table 8: Viewpoints regarding migration

\begin{tabular}{|c|c|c|c|c|}
\hline S.No & Viewpoints regarding initial migrating issues & Sample (N) & Percentage (\%) & $P$ value \\
\hline \multirow[t]{6}{*}{1.} & If migration attempt failed & & & $0.0001(<0.01)$ \\
\hline & I would continue to make repeated attempts & 291 & 54 & \\
\hline & I would stick to staying Pakistan & 75 & 13.9 & \\
\hline & I would think about making a re-attempt later in life & 159 & 29.5 & \\
\hline & Does not apply to me & 14 & 2.6 & \\
\hline & Total & 539 & 100 & \\
\hline \multirow[t]{5}{*}{2.} & \multicolumn{2}{|c|}{ Advice to others regarding migration attempt } & & $0.0001(<0.01)$ \\
\hline & Migrate from Pakistan & 207 & 38.4 & \\
\hline & Stay in Pakistan & 130 & 24.1 & \\
\hline & I am indecisive & 202 & 37.5 & \\
\hline & Total & 539 & 100 & \\
\hline
\end{tabular}

\section{Table 9: Preparations towards migration}

\begin{tabular}{|c|c|c|c|c|}
\hline S.No. & Preparatory measures & Observed (N) & Percentage (\%) & $P$ value \\
\hline \multirow[t]{7}{*}{1.} & \multicolumn{3}{|c|}{ Foreign pharmacy licensing exam students likely to appear in } & $0.0001(<0.01)$ \\
\hline & NAPLEX & 228 & 42.3 & \\
\hline & OSPAP & 64 & 11.9 & \\
\hline & PBA & 61 & 11.3 & \\
\hline & $\mathrm{DHA} / \mathrm{MOH}$ & 16 & 3 & \\
\hline & PEBC, PSI, PCNZ & 170 & 31.5 & \\
\hline & Total & 539 & 100 & \\
\hline \multirow[t]{4}{*}{2.} & \multicolumn{3}{|c|}{ Will to attend special preparatory classes for exams } & $0.0001(<0.01)$ \\
\hline & Yes & 434 & 80.5 & \\
\hline & No & 105 & 19.5 & \\
\hline & Total & 539 & 100 & \\
\hline \multirow[t]{4}{*}{3.} & \multicolumn{3}{|c|}{ Receive any guidance regarding migration } & $0.0001(<0.01)$ \\
\hline & Yes & 366 & 67.9 & \\
\hline & No & 173 & 32.1 & \\
\hline & Total & 539 & 100 & \\
\hline \multirow[t]{7}{*}{4.} & \multicolumn{3}{|c|}{ Medium of guidance regarding migration } & $0.0001(<0.01)$ \\
\hline & Internet & 127 & 23.6 & \\
\hline & Consultants & 205 & 38 & \\
\hline & Others & 151 & 28 & \\
\hline & Both & 16 & 3 & \\
\hline & Not guided & 40 & 7.4 & \\
\hline & Total & 539 & 100 & \\
\hline
\end{tabular}

quit pharmacy profession for an unrelated profession abroad if need be. The mean Likert score (3.77, SD 1.4) reveals confusion in minds of pharmacy students. Furthermore, to the question of the will to change pharmacy career domain abroad if need arise, the mean Likert score was 3.43 (SD 1.5) which shows that the general population was reluctant to change their career domain.
In response to the question of intention to apply citizenship abroad if given an opportunity, the mean Likert score was (2.00, SD 1.3) which implies that pharmacy students have a desire to seek citizenship. In addition to this, they were asked if they would take their family abroad after acquiring citizenship and mean score obtained was 1.81 (SD 1.2) hence indicating that they would prefer to take their families along. However, to 
Table 10: Cross tabulation between professional year of study and migration variable

\begin{tabular}{|c|c|c|c|c|c|c|c|c|c|}
\hline S.No & Cross tabulation & \multicolumn{6}{|c|}{$\begin{array}{c}\text { Professional Year }(\mathrm{N}=539) \\
\text { Observed count (Expected count) }\end{array}$} & Chi square & $P$ - value \\
\hline \multirow[t]{5}{*}{1.} & \multicolumn{7}{|c|}{ Wish to migrate } & 29.617 & $0.001(<0.01)$ \\
\hline & & 1st Year & 2nd Year & 3rd Year & 4th Year & 5th Year & $\begin{array}{c}\text { Pharmacy } \\
\text { Resident I } \\
\text { 6th Year }\end{array}$ & & \\
\hline & Yes & $114(112)$ & $100(99.5)$ & $80(94.2)$ & $65(62.2)$ & $85(80)$ & $35(31.1)$ & & \\
\hline & No & $11(11.2)$ & $9(10)$ & $21(9.4)$ & $4(6.2)$ & $3(8)$ & $0(3.1)$ & & \\
\hline & Not sure & $1(2.8)$ & $3(2.5)$ & $5(2.4)$ & $1(1.6)$ & $2(2)$ & $0(0.8)$ & & \\
\hline 2. & \multicolumn{6}{|c|}{ Received guidance regarding migration } & & 29.005 & $0.0001(<0.01)$ \\
\hline & Yes & $73(85.6)$ & $69(76.1)$ & $65(72)$ & $62(47.5)$ & $70(61.1)$ & $27(23.8)$ & & \\
\hline & No & $53(40.4)$ & $43(35.9)$ & $41(34)$ & $8(22.5)$ & $20(28.9)$ & $8(11.2)$ & & \\
\hline 3. & \multicolumn{7}{|c|}{ Medium of guidance regarding migration } & 66.506 & $0.0001(<0.01)$ \\
\hline & Websites & $32(29.7)$ & $24(26.4)$ & $26(25)$ & $9(16.5)$ & $31(21.2)$ & $5(8.2)$ & & \\
\hline & Consultants & $35(47.9)$ & $45(42.6)$ & $50(40.3)$ & $38(26.6)$ & $32(34.2)$ & $5(13.3)$ & & \\
\hline & Both & $9(3.7)$ & $3(3.3)$ & $0(3.1)$ & $3(2.1)$ & $1(2.7)$ & $0(1)$ & & \\
\hline & Others & $40(35.3)$ & $25(31.4)$ & $25(29.7)$ & $18(19.6)$ & $24(25.2)$ & $19(9.8)$ & & \\
\hline & Not guided & $10(9.4)$ & $15(8.3)$ & $5(7.9)$ & $2(5.2)$ & $2(6.7)$ & $6(2.6)$ & & \\
\hline \multirow[t]{4}{*}{4.} & \multicolumn{6}{|c|}{ Advice to others regarding migration } & & 29.443 & $0.001(<0.01)$ \\
\hline & $\begin{array}{l}\text { Migrate from } \\
\text { Pakistan }\end{array}$ & $43(48.4)$ & $39(43)$ & $41(40.7)$ & $38(26.9)$ & $41(34.6)$ & $5(13.4)$ & & \\
\hline & Stay in Pakistan & $36(30.4)$ & $30(27)$ & $32(25.6)$ & $9(16.9)$ & $11(21.7)$ & $12(8.4)$ & & \\
\hline & I am indecisive & $47(47.2)$ & $43(42)$ & $33(39.7)$ & $23(26.2)$ & $38(33.7)$ & $18(13.1)$ & & \\
\hline
\end{tabular}

the question of returning to Pakistan after acquiring foreign citizenship, the score was 2.09 (SD 1.2) thus supporting the fact that despite acquiring citizenship the pharmacy student prefer to return to Pakistan.

Additionally, the students were asked if they are willing to relinquish Pakistani nationality if required by law of any foreign country, the mean Likert score obtained was 3.55 (SD 1.6) which implies that students' mindset is against giving up on Pakistani nationality. Similarly, the mean Likert score obtained for the question regarding the will to migrate despite knowing that Pakistan needs pharmacy professionals was 2.19 (SD 0.7) which implies that students feel bad about leaving Pakistan in this situation. The detailed analysis of attitude of pharmacy students towards migration is tabulated in Table 7.

\section{Student viewpoints regarding initial migrating issues}

In case of a failed migrating attempt, more than half of the students $(\mathrm{N}=291,54 \%)$ viewed immediate re-attempt as most logical option followed by almost a third proportion $(\mathrm{N}=159,29.5 \%)$ which viewed re-attempt at a later time. This question did not apply to dual nationals $(\mathrm{N}=14,2.6 \%)$.

Furthermore, the students were asked about their advice to others regarding migration from Pakistan and majority
$(\mathrm{N}=207,38.4 \%)$ responded advising to migrate from Pakistan followed by those $(\mathrm{N}=202,37.5 \%)$ who appeared indecisive. Some students $(\mathrm{N}=130,24.1 \%)$ advised to stay in Pakistan. The summary of views regarding migration is tabulated in Table 8.

\section{Preparedness and aptitude for migration}

In response to aptitude test, almost half of the target segment $(\mathrm{N}=228,42 \%)$ aimed to give North American Pharmacy Licensure Examination NAPLEX followed by similar proportions of students who were eager to take the Overseas Pharmacist Assessment Program OSPAP of the UK $(\mathrm{N}=64,11.9 \%)$ and licensing examination of Pharmacy Board of Australia PBA $(\mathrm{N}=61,11.3 \%)$. An overwhelming majority of pharmacy students $(\mathrm{N}=434,80.5 \%)$ were willing to attend preparatory classes and sessions for foreign pharmacy licensing exams. More than half of the pharmacy students surveyed $(\mathrm{N}=366,68 \%)$ received guidance about migration information. Furthermore, the most common medium of guidance was taking advice of consultants ( $\mathrm{N}=205,38 \%$ ) followed by internet browsing $(\mathrm{N}=127,23.6 \%)$. A small segment $(\mathrm{N}=40,7.4 \%)$ did not receive or seek any guidance in this regard. The summary of preparatory measures of students is presented in Table 9. 


\section{Cross tabulation of professional study year with migration trends}

The association between professional study year of pharmacy students and their wish to migrate abroad was significant. The chi square value reported was 29.61 and $\mathrm{p}$ value was 0.001 . The strength of $p h i$ is moderate i.e. 0.234 . The association between professional study year and receiving guidance regarding migration was also significant with chi square value reported at 29.005 and $\mathrm{p}$ value at 0.0001 . The strength of $p h i$ is moderate i.e. 0.232 . The association of professional year and medium of guidance was statistically significant with chi square value reported 66.506 and $\mathrm{p}$ value i.e. 0.0001 with strong phi 0.351 effect size. The association of professional year and advice to others regarding migration was statistically significant i.e. chi square value 66.506 and $\mathrm{p}$ value i.e. 0.001 with strong $p h i$ value 0.234 . The summary of cross tabulation is presented in Table 10.

\section{DISCUSSION}

Pakistan has witnessed a rise in the migration of professionals from the country in the last few years eventually leading to a brain drain. ${ }^{16,17}$ This phenomenon has been reported in a number of studies and by various news agencies as well. ${ }^{18,19}$ Sheikh et al. 2012 reported rising urge to emigrate from Pakistan particularly in undergraduates. ${ }^{16}$ In an another study the brain drain among pharmacy teaching professionals in Pakistan's pharmacy education has been reported however, none of the studies reported migration trends of the pharmacy students of Pakistan. ${ }^{20}$ This study aimed to investigate the inclination towards migration among pharmacy students of Pakistan and unlike previous studies; it was conducted in pharmacy teaching institutes of 3 major cities of Pakistan namely Karachi, Lahore and Islamabad.

Five hundred and thirty nine (539) responses were gathered and analyzed from pharmacy students. The mean age of the students and the male to female ratio reported in the study represents the characteristic Pakistani pharmacy education environment which is dominated by females. ${ }^{21,22}$ The prevalence rate reported for migration intention was quite high i.e. $94.06 \%$ $(91.72 \%-95.90 \%$ for $95 \%$ CI) as compared to the studies reporting migration intention among medical students. Furthermore, the urgency to migrate as measure on a scale of 10 was reported at 6.42 (SD 2.49). The factors such as lucrative opportunities abroad, political instability, lack of opportunities and security issues encourage young students to migrate. ${ }^{16,17}$

It is pertinent to mention that most of pharmacy students wish to pursue a career in pharmaceutical sector in Pakistan but switch to clinical and hospital sector as their career choice abroad. This change in career choice is due to the fact that Pakistan's pharmaceutical sector is widely seen as the area with opportunities for young pharmacy graduates offering better salaries as compared to the health care sector of the country which is incapacitated and lacks infrastructure. ${ }^{23}$ Moreover, the salary scale of pharmacists in health care system of Pakistan is very low and regulatory issues render all authority and professional clout to physicians hence limiting the role and learning opportunities for pharmacists. ${ }^{24} \mathrm{On}$ the other hand, the pharmaceutical sector of Pakistan offers better salaries and more learning opportunities hence becoming the first career choice of pharmacy students. Contrary to the situation in Pakistan, clinical and hospital pharmacy sectors are well developed in the foreign countries. They offer lucrative salaries to pharmacists as well as opportunities for continued professional development Moreover, in order to practice as pharmacists abroad, pharmacy graduates need to clear licensing exam which is heavily dominated by clinical knowledge. ${ }^{25}$ Therefore students are more inclined to select clinical and health sector as their preferred area for specialization and career abroad.

The study also investigated factors with the potential to either pull or push pharmacy students towards Pakistan or abroad hence categorized as pull and push factors. Students mentioned family ties, patriotism and the desire to serve their homeland as major pull factors of Pakistan. To enhance the understanding of these pull factors it is quite important to mention that Pakistan is a country with a social compilation of different communities of close knitted family structures which are further connected to a wider community based on religion, sect, tribe, race, etc. This close knitted family structure is further fortified with the teaching of Islam; the dominant religion practiced in the country which emphasizes family values and hence the younger generation is ingrained with the idea of upholding family values. ${ }^{26}$ The desire to serve the country coupled with strong family ties thus influences many Pakistani professionals and students to remain in the country and choose not to opt for migration. Major push factors of Pakistan reported in this study were lack of infrastructure for pharmacy profession and security issues. The situation of Pakistan's health care system is quite depressing as it is financially incapacitated to handle the needs of patients as well as professionals working in the system. The health care system of Pakistan is physician centered thus providing authority over finances and legislations to them hence they find themselves in a position of command and unprecedented powers. ${ }^{24}$ 
Pakistan has been a victim of security issues for the last fifteen (15) years resulting in damage to property and loss of lives. Not only the unskilled professionals but graduates and highly skilled professionals migrated from the country in last few years with the number of migrants soaring to 2.7 million in the last 5 years. ${ }^{18}$ However, majority of the students showed optimism in reversing their decision to migrate from Pakistan if the push factors were neutralized.

The major pull factors of migrating abroad were more employment opportunities and lucrative salaries. This may be attributed to the fact that pharmacy profession in developed countries is more advanced and sophisticated requiring more human resource thereby creating more employment opportunities. The reason behind the perception of lucrative salaries becoming a pull factor in the minds of the students can be explained from the exchange rate conversion. Pakistan's Rupee has been losing its value considerably against the US Dollar since 1988. In 2013-14 the US Dollar rose to an all time high of 108.6 PKR i.e. highest ever in the history of Pakistan. ${ }^{27}$ This widening gap in the exchange rates is usually viewed by many as earning lucrative salaries. It brings an intuitive calculation of the minimum wages earned in a non-pharmacy job abroad which turns out to be more than what one newly graduated pharmacist is to earn in a professional portfolio in Pakistan.

On the other hand, the push factor of developed countries highlighted by majority of students was tough pharmacy licensing exams. This can be best explained by the level of pharmacy education in Pakistan. Being a developing country, Pakistan's pharmacy education system lacks quality approaches in teaching and assessments as well as expertise in pharmacy practice courses especially clinical pharmacy. Moreover, the underdeveloped health care structure limits the practical exposure of the pharmacists in a health care setting such as areas of patients counseling, prescription writing of pharmacists and clinical pharmacy services. ${ }^{15,25,28}$

These gaps have the potential to become a hurdle in passing foreign pharmacy licensing exam since a large part of these exams comprise of the clinical knowledge. Moreover, requirement of competent professional English language skills as a co requisite, escalating fee structure for exams and an expensive document evaluating procedure makes it even more difficult.

Majority of the students highlighted USA as their destination of choice. It is worthwhile mentioning that the US is a multicultural society which incorporates people from different religious, racial and linguistic backgrounds and those who migrate to USA can easily find people from same community. As a result, it is easy to settle in the US as compared to any other country in the world. ${ }^{29}$ Moreover, the other major countries highlighted by students were Canada and Australia. Unlike USA, Canada has flexible immigration rules and an electronic immigration program which has recently been initiated to facilitate immigration applications of eligible candidates swiftly. It is a country which seems quite welcoming to immigrants from all over the world..$^{30}$ Although Australia is quite similar to Canada in terms of its immigration policies and society in general, currently employment opportunities for pharmacists are unclear as the country removed pharmacy profession from its occupation list since $2013{ }^{31,32}$ Furthermore, majority of the students highlighted the pull factors of migrating abroad as their reason to migrate to afore mentioned countries.

In addition, the migratory attitude of pharmacy students was documented on a 5 point Likert Scale where the value of 1 represented a strong agreement and value of 5 represented most vague or absolute negative response. In response to the question of willing to stay in Pakistan despite security issues, the general response of participants was emigrating from Pakistan. Security issue was also highlighted by the respondents as a major push factor of Pakistan. Apart from this, respondents appeared confused regarding quitting pharmacy profession after migrating abroad and/or changing a career domain in pharmacy. The reason for this confusion is the fact that all respondents were undergraduate pharmacy students at different levels hence at this point, a student aims to focus on the scope of the pharmacy degree only thus it is not easy to shift that frame of mind to consider an alternative such as quitting or changing one's own profession.

The students aspired to apply for citizenship in their country of choice after migration and were also willing to take their families along. Paradoxically, the students were not in favor of relinquishing Pakistani nationality, felt bad leaving Pakistan in a state of brain drain and were determined to return to Pakistan after acquiring citizenship abroad. In addition, majority of the students were willing to retry if they fail in their initial attempt of foreign immigration application and even advised others to migrate from Pakistan.

Regarding preparedness and aptitude, most of the pharmacy students had received career guidance and appeared to be more poised in knowledge seeking and decision making. Bulk of the students opted for North American Pharmacy Licensure Examination (NAPLEX) which is in accordance with the earlier findings where majority highlighted USA as their career destination and an overwhelming majority of pharmacy 
students appeared willing to attend special preparatory classes for foreign pharmacy license examinations.

The common medium of guidance for emigration procedure was through consultants and internet. In relation to this, it is worth mentioning that pharmacy institutions and private organizations have also started to provide career guidance seminars as a part of their academic activities with lectures by consultants on career domain selection, license exam preparation, emigrating opportunities and higher education abroad.

\section{CONCLUSION}

The pharmacy students of Pakistan appear ingrained with the thought of emigrating from Pakistan with a high urgency. This notion is fortified by the pull factor of developed countries i.e. lucrative salary and reinforced negatively by the push factors of Pakistan such as security issues. However, Pakistan's major pull factors i.e. family ties and patriotism have the potential to reduce the brain drain to some extent if its push factors are neutralized.

Pharmacy students are now seeking information during their undergraduate academic career and are better poised in decision making. Students aspire to acquire foreign citizenship after migration and also appear determined to return to Pakistan at some point in time. There is a feel of remorse in the minds of students who want to leave Pakistan.

This encouragement is enough to support the hypothesis that if Pakistan as a nation prospers and overcomes the challenges of security, improves its health care system and infrastructure for pharmacists, its pull factors have the potential to overpower foreign desirability. Nonetheless, the extent to which the pull factors of abroad can be negated, remains a point of debate.

\section{ACKNOWLEDGEMENT}

All authors would like to thank the students for taking their time and providing their honest responses. The authors would also like to thank Mr. Mohammad Nehal Nadir and Miss Nida Yazdani for extending their support in the research project.

\section{CONTRIBUTION OF AUTHORS}

AA conceived the idea with FZ and designed the study. SU wrote the introduction and assisted SR, IY, SJ in data collection, data entry into SPSS and data analysis. AA wrote the methods and results with RA and NA. FZ wrote abstract, discussion and conclusion with AA. The whole project was supervised by SBSN. RA, NA and
FZ carried out extensive editing of the manuscript and assisted in the revision. All authors read and approved the final version.

\section{CONFLICT OF INTEREST}

None declared.

\section{ABBREVIATIONS USED}

PCP: Pharmacy Council of Pakistan; WHO: World Health Organization; USA: United States of America; UK: United Kingdom; Pharm.D: Doctor of Pharmacy; B.Pharm: Bachelor of Pharmacy; USD: United States Dollar; SPSS: Statistical Package for Social Sciences; NAPLEX: North American Pharmacy Licensure Examination; OSPAP: Overseas Pharmacist Assessment Program; PBA: Pharmacy Board of Australia; DHA: Dubai Health Authority; MOH: Ministry of Health (Dubai); PEBC: Pharmacy Examining Board of Canada; PSI: Pharmaceutical Society of Ireland; PCNZ: Pharmacy Council of New Zealand.

\section{REFERENCES}

1. List of 57 countries facing Human Resources for Health crisis. Global Health Workforce Alliance. World Health Organization; 2006. http://www.who.int/ workforcealliance/countries/57crisiscountries.pdf. Accessed 14 November 2016.

2. Bureau of Emigration and Overseas Employment, Government of Pakistan. Migration of Physicians; http:// www. beoe.gov.pk Accessed 14 November 2016.

3. Recognition status of pharmacy institutions. Pharmacy Council of Pakistan (PCP); 2016. ttp://www.pharmacycouncil.org.pk/PI.php. Accessed 14 November 2016.

4. WHO Global Code of Practice on International Recruitment of Health Personnel. Implementation strategy report. Global Health Workforce allaince. World Health Organization (WHO); 2011. http://www.who.int/ workforcealliance/knowledge/resources/PAK_ImmigrationReport.pdf Accessed 14 November 2016

5. FIP Global Pharmacy Workforce Report. International Pharmaceutical Federation; 2012. http://fip.org/files/members/library/FIP_workforce_ Report_2012.pdf. Accessed 15 November 2016.

6. Pharmaceutical Country Profile for Pakistan. World Health Organization (WHO); 2010. http://www.who.int/medicines/areas/coordination/pakistan.pdf. Accessed 15 Novemebr 2016.

7. Iredale R. The Migration of Professionals: theories and Typologies. International Migration. 2001;7-26. https://doi.org/10.1111/1468-2435.00169.

8. Ahmed SI, Ahmad Hassali MA. The Controversy of Pharm D Degree. American Journal of Pharmaceutical Education. 2008;15:71-2. https://doi. org/10.5688/aj720371.

9. Kasey K. The "Brain Drain": Migration of Healthcare Workers out of subSaharan Africa; 2012. http://med.stanford.edu/schoolhealtheval/files/ KissickBrainDrainFactSheetFinal.pdf. Accessed 15 November 2016.

10. Islamabad. Wikipedia. 2016. http://en.wikipedia.org/wiki/lslamabad Accessed 15 November 2016.

11. Lahore. Wikipedia. 2016. http://en.wikipedia.org/wiki/Lahore Accessed 16 November 2016.

12. Karachi. Wikipedia. 2016. http://en.wikipedia.org/wiki/Karachi Accessed 16 November 2016.

13. Azhar S, Hassali MA, Mohamed Ibrahim MI, Ahmad M, Masood I and Shafie AA. The role of pharmacists in developing countries: the current scenario in 
Pakistan. Hum Resour Health. 2009;7:54. https://doi.org/10.1186/14784491-7-54 PMid:19594916 PMCid:PMC2714831.

14. Creative Research Systems. Sample size calculator. http://www. surveysystem.com/sscalc.htm Accessed 20 November 2016.

15. Abbas A. The catch-22 of Pharmacy Practice in Pakistan's Pharmacy Education. Pharmacy. 2014;2:202-4. https://doi.org/10.3390/pharmacy2030202.

16. Sheikh A, Abbas Naqvi SH, SheikhK, Shiraz Naqvi SH. Physician migration at its roots: a study on the factors contributing towards a career choice abroad among students at a medical school in Pakistan. Globalization and Health. 2012;8:43. https://doi.org/10.1186/1744-8603-8-43 PMid:23241435 PMCid:PMC3542032.

17. Ahmad M. Brain drain plaguing Pakistan. The News International. 2014. http://www.thenews.com.pk/Todays-News-3-255019-Brain-drain-plaguingPakistan Accessed 25 November 2016.

18. Brain drain: $2.7 \mathrm{~m}$ Pakistanis have exited country in last 5 years. The Tribune; 2013. http://tribune.com.pk/story/649347/brain-drain-2-7m-pakistanis-haveexited-country-in-last-5-years/ Accessed 25 November 2016.

19. Sajjad N. Causes and Solutions to Intellectual Brain Drain in Pakistan. The Dialogue. 2011;6:31-55.

20. Abbas A, Khan N. The Brain Drain of Qualified Clinical Pharmacy Professionals in Pakistan's Pharmacy Education: A Retrospective Study. Pharmacy Regulatory Affairs: Open Access. 2015;4-130.

21. Abbas A, Ahmed FR, Yousuf R, Khan N, Nisa ZU, Ali SI, et al. Prevalence of Self-Medication of Psychoactive Stimulantsand Antidepressants among Undergraduate PharmacyStudents in Twelve Pakistani Cities. Trop J Pharm Res. 2014;14:527-532. https://doi.org/10.4314/tjpr.v14i3.23.

22. Abbas A, Rizvi SA, Hassan R, Aqeel N, Khan M, Bhutto A, Khan Z, Mannan Z. The prevalence of depression and its perceptions among undergraduate pharmacy students. Pharmacy Education. 2015;15(1):57-63.
23. Pakistan Health System Strengthening. WorldHhealth Organization WHO; 2015. http://www.emro.who.int/pak/programmes/health-systemstrengthening-hss.html Accessed 25 November 2016.

24. Gera N. Pakistan's Health Care Under Structural Adjustment. The Lahore Journal of Economics. 2003;8:65.

25. Abbas A. Evidence Based Improvements in Clinical Pharmacy Clerkship Program in Undergraduate Pharmacy Education: The Evidence Based Improvement (EBI) Initiative. Pharmacy. 2014;2:270-5. https://doi. org/10.3390/pharmacy2040270.

26. Building Asian Families and Communities in the $21^{\text {st }}$ Century: Selected Proceeding of the 2nd Asian Psychological Association Conference Kuala Lumpur, Malaysia. 2008. https://books.google.com.pk/books?id= hAkaBwAAQBAJ\&pg=PA434\&lpg=PA434\&dq=pakistan+close.

27. Pakistan rupee. Trading economics; 2016. http://www.tradingeconomics. com/pakistan/currency Accessed 25 November 2016.

28. Abbas A, Khan N. Clinical Trials Involving Pharmacists in Pakistan's HealthcareSystem: A Leap from Paper to Practice. Pharmacy. 2014;2:244-247. https://doi.org/10.3390/pharmacy2030244.

29. Why do people want to immigrate to the United States? 2014. https:// www.quora.com/Why-do-people-want-to-immigrate-to-the-United-States Accessed 25 November 2016.

30. Immigrate as a skilled worker through Express Entry. Government of Canada; 2015. http://www.cic.gc.ca/english/Immigrate/skilled/index.asp Accessed 25 November 2016.

31. Why Emigrate to Australia? Australian Visa Beareu; 2015. http://www. visabureau.com/australia/why-australia.aspx Accessed 25 November 2016.

32. Pharmacist Job in Australia. Australian Visa Beaureu; 2015. http://www. visabureau.com/australia/anzsco/jobs/pharmacist-job-australia.aspx Accessed 27 November 2016.

Cite this article: Naqvi AA, Zehra F, Naqvi SBS, Ahmad R, Ahmad N, Usmani S, Badar S, Younus I, Khan JS. Migration Trends of Pharmacy Students of Pakistan: A Study Investigating the Factors Behind Brain Drain of Pharmacy Professionals from Pakistan. Indian J of Pharmaceutical Education and Research. 2017;51(2):192-206. 